\title{
Surface-Modified Porous Polymeric Membrane Using Vesicles
}

\author{
Jj-Youn Im, Sang-Hee Lee, ${ }^{\dagger}$ Suck-Beom Ko, ${ }^{\ddagger}$ Kuk-Haeng Lee, ${ }^{\ddagger}$ and Youn-Sik Lee* \\ Division of Enviromental and ( hemical Fngineering, The Research Instime of Industral Techologb, \\ ('honhut Kational Iniversity, (Thonit 561-756, Norea \\ ${ }^{\dagger}$ Department of Chemistry. Kunsan National Thiversin, (innsan 573-360, Korea

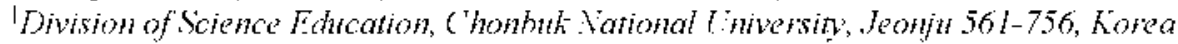 \\ Received Jithe 24, 2002
}

\begin{abstract}
If the surfaces of vesicles are chemically modified so that they can be dispersed in organic solvents, the application of vesicular colloids may be expanded. $\Lambda$ polymerizable surfactant (BD $\Lambda C$ ) and nonpolymerizable bipolar surfactant (BP' $\Lambda$ S) were synthesized in multi-steps. Large vesicles composed of BD $\Lambda C^{\prime}$ and BI' $\Lambda$ S with embedded a cross-linking agent (diviny lbenzene) undervent a radical polýmetization. BI' $\triangle$ S was extracted out using methanol (skeletonization). 'The headgroup of $B D \wedge C$ was cleaved oft via hydrolysis in an acidic condition to yield resicles where surfaces were covered with -COOH groups. There was no significant cliange in the overall shape. The skeletonized vesicles appear to have many holes with dianeters up to about 25 nm. 'The holes tetained even after hydrolysis. The hydrolyzed vesicles were not dispersed in water and most organic solvents such as tetrahydrofuran and chlorofom, but dispersed in methanol.
\end{abstract}

Key Words : Vexicle, Polymerizahle surlactant, Skelelonization, Hydrolysis

\section{Introduction}

Lipid molecules can be spontancously aggregated into spherically closed bilayers. i.e. vesicles in water. These vesicular morphologics have found a multitude of applications in various scientific and applied ficlds in recent years. However. the stability of the vesicles is still a scrious problem. One common approach for stabilizing vesicles is the polymerization of membranc components in the bilayers. The polymerizable groups in the lipid molecules have becn incorporated in the head group or in the alkyl clain at different positions relative to the head group. ${ }^{\text {l.2 }}$

A rather fascinating biomembrane process was obsenced in the deatl of a tumor cell that cannot cscape from the immume system. ${ }^{3}$ An activated macroplage atlacked a tumor cell and drilled holes in the originally stable tumor cell membrane. As a result. the cytoplasmic interior leaked out. which caused the death of the tumor cell. In order to simulate the biological process. phase-separated resicles were used initially by Rinsdorf and coworkers. ${ }^{3}$ Tsuclida and coworkers also prepared skelelonized (drilled) lybrid liposomes using the plase separation whicl was induced upon polymerization of liposomes composod of polymerizable and non-polymerizable surfactants."

The surfaces of reported drilled or skeletonized vesicles are hydrophilic. If the hydrophilic surfaces are chemically modified to be reasonably compatible with organic solyents. the application of resicular colloids can be cxpandod since the porous particles may be dispersed in common organic media.

Recently: we reportod vesicles composed of a polynerizable surfactant. a non-polymerizable lipid. and a cross-linking

\footnotetext{
"lo whom correspondenee should be addressed. e-mail: yosklear iache.chonbuk ac.kr
}

agent. which was N.N-bis[10-(4-y inylben/y loxy)decanoylaminocthỵ]l-N.N-dimellỵlammonium chloride (BDAC). 1.2dipalmiloyl-sh-glycero-3-phosphocholine (DPPC). and divinylbenzene (DVB). respectively. When the small unilamellar vesicles of BDAC and DPPC with embedded DVB were poly merized at $60^{\circ} \mathrm{C}$. most of the vesicles retained their initial splicrical shapes. bul a so-called parachulc-like morphology was also occasionally obsened. The paraclute-like struclure probably resulied from the polymerization of DVB procecded in the bilayer in a latex-like fashion due to the phase scparation betwecn the DVB polymer and polymeri\%ed BDAC bilayer. When the polymerization was performed again with large multilamellar vesicles and at a lower lemperature of $55^{\circ} \mathrm{C}$. 1he parachulc-like morphology could not be obsencd. However. the holes in the large multilamellar vesicle membranes. which were formed by the removal of DPPC from the polymerized membrane matrix. were 100 small to be sludicd in detail.

In this study. a 4.4'-biphenol-bascd teiraclly lammonium salt (BPAS) was used instead of DPPC as a nonpolymerizable component. as shown in Figure 1. The +.4'biphenol moicty of BPAS was expected to prevent the ampliphile from being vent (U-shaped) in the vesicle membranes because it is a rigid segment. The reason for using the bipolar surfactant was that it can span the vesicle membrancs. leading to the fommation of holes which can also span the cross-linked membrane matrix on the removal of it. This paper describes the synthesis of BDAC and BPAS and some results on the surface modification of the vesicles prepared from the two different surfactants.

\section{Experimental Section}

10-(4-Vinylhenzyloxy)decan-1-ol (1-1). A solution of 


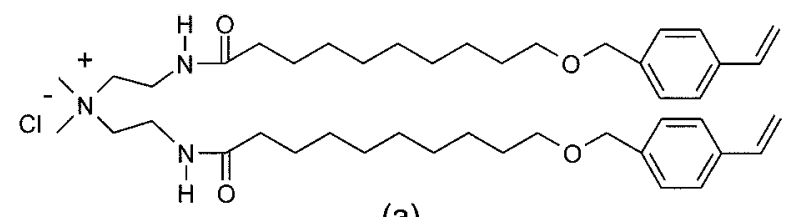

(a)

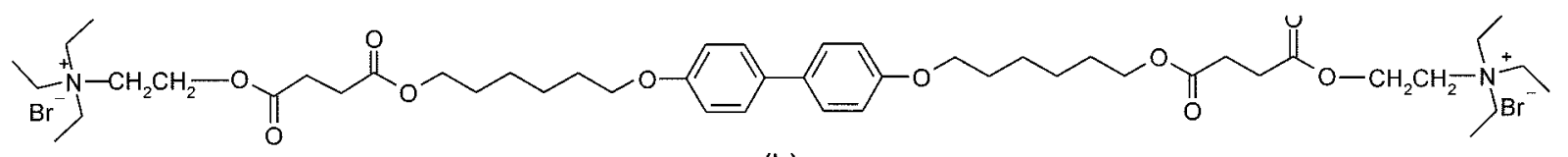

(b)

Figure 1. Chemical structures of (a) BDAC and (b) BPAS.

1.10-decanediol (2.28 g. $13.1 \mathrm{munol})$ and 4-viny lbeluzyl chloride (2.0 g. $13.1 \mathrm{mmmol}$ ) in DMF (20 $\mathrm{mL})$ was refluxed for $2+\mathrm{h}$ at $150{ }^{\circ} \mathrm{C}$. The reaction mixture was poured into a separatory funnel containing $100 \mathrm{~mL}$ of water. The resulting mixture was extracted with diethyl ether $(5 \times 50 \mathrm{~mL})$. The ether plase was washed with $50 \mathrm{~mL}$ of water $(5 \times 50 \mathrm{~mL})$, dried over sodium sulfate. concentrated under a reduced pressure. and finally separated by flash column chromatography (hexane/etlyl acetate $=8 / 2 . \mathrm{R}_{\mathrm{l}}=0.3$ ) to obtain $1.5 \mathrm{~g}$ of compound 1-1 as a solid (50\%). IR (KBr, $\left.\mathrm{cm}^{-1}\right) 3407.1100$. ${ }^{3} \mathrm{H}-\mathrm{NMR}\left(\mathrm{CDCl}_{3}\right) \delta 1.23-1.90\left(\mathrm{~m} . \mathrm{l} 6 \mathrm{H},\left(\underline{\mathrm{CH}_{2}}\right)_{8}\right) .3 .60(\mathrm{t},+\mathrm{H}$.

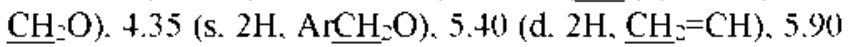
(d. $\left.2 \mathrm{H} . \underline{\mathrm{CH}_{2}}=\mathrm{CH}\right) .6 .75$ (dd. $\left.\left.1 \mathrm{H}, \mathrm{CH}_{2}=\underline{\mathrm{CH}}-\mathrm{Ar}\right) .7 .45-7.60\right)(\mathrm{mL}$ 4H. Ar)

10-(4-Vinylbenzyloxy)decanoic acid (1-2). Pyridiuium dicluromate $(5.18 \mathrm{~g} .14 \mathrm{mmol})$ was dissolved in $10 \mathrm{~mL}$ of DMF and cooled in an ice bath. followed by the addition of compound 1-1 (1.0 g. $3.5 \mathrm{mmol}$ ) in $2 \mathrm{~mL}$ of DMF. The resulting dark brown mixture was stirred for $16 \mathrm{~h}$ at room temperature. and poured into a separatory funnel containing $100 \mathrm{~mL}$ of $5 \% \mathrm{HCl}$ aqueous solution. The mixture was extracted with diethyl ether $(5 \times 25 \mathrm{~mL})$. The ether phase was washed with water $(5 \times 25 \mathrm{~mL})$, dried over sodium sulfate, concentrated under a reduced pressure, and separated by flash column chromatography (hexane/ethỵl acetate $=7 / 3, R_{\imath}=0.3$ ) to obtain $0.7 \mathrm{~g}$ of compound 1-2 as a solid $(70 \%)$. IR (KBr. cm$\left.{ }^{-1}\right) 3400-2400,1710,1100$. 'HNMR $\left(\mathrm{CDCl}_{3}\right) \delta 1.23-1.90\left(\mathrm{~m} .16 \mathrm{H},\left(\underline{\mathrm{CH}}_{2}\right)-\right) .2 .30$ (t. $2 \mathrm{H}$, $\mathrm{CH}_{2} \mathrm{CO}_{2}$ ). 3.60 (t. $2 \mathrm{H}, \mathrm{CH}_{2} \mathrm{O}$ ). +.35 (s, $2 \mathrm{H} . \mathrm{ArCH}_{2} \mathrm{O}$ ), 5.40 (d. $\left.2 \mathrm{H} . \mathrm{CH}_{2}=\mathrm{CH}\right) .5 .90$ (d. $\left.2 \mathrm{H} . \underline{\mathrm{CH}}_{2}=\mathrm{CH}\right) \cdot 6.75$ (dd. $1 \mathrm{H}$. $\left.\mathrm{CH}_{2}=\underline{\mathrm{CH}}-\mathrm{Ar}\right), 7.45-7.60(\mathrm{~m}, 4 \mathrm{H}, \mathrm{Ar})$.

Methyl-bis[2-\{10-(4-vinylbenzyloxy)decanoylamino\}ethyllamine (1-3). A solution of compound 1-2 (1.0 g. 3.3 munol)、N-methỵl-2.2 ${ }^{*}$-diaminodiethỵlamine $(0.20 \mathrm{~g}, \quad 1.7$ mumol), dicyclohexyldimide (DCC) (0.80 g. $3.9 \mathrm{mmol})$. and N.N-dimethylaminopy ridine (DMAP) $(0.0+\mathrm{g} .0 .33 \mathrm{mmol})$ in $10 \mathrm{~mL}$ of chloroform was stirred for $2 \mathrm{~h}$ at room temperature. Dicyclohexylurea was filtered off. The reaction mixture was concentrated under a reduced pressure and separated by flash column chromatography $\left(\mathrm{CH}_{2} \mathrm{Cl}_{2} /\right.$ $\mathrm{MeOH}=20 / \mathrm{L} . \mathrm{R}_{\mathrm{f}}=0.2$ ) to obtain $0.80 \mathrm{~g}$ of compound 1-3 (73\%). IR ( $\left.\mathrm{KBr} . \mathrm{cm}^{-1}\right) 16+0,1100 .{ }^{1} \mathrm{H}-\mathrm{NMR}\left(\mathrm{CDCl}_{3}\right) \delta$ $1.23-1.90\left(\mathrm{~m} .28 \mathrm{H},\left(\underline{\mathrm{CH}_{2}}\right)\right), 2.30-2.50\left(\mathrm{~m} .11 \mathrm{H}, \underline{\mathrm{CH}}_{3} \mathrm{~N}\right.$.

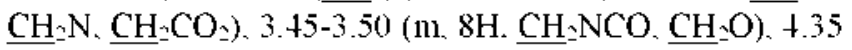

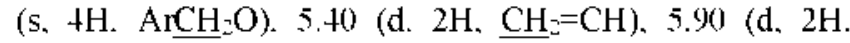
$\left.\underline{\mathrm{CH}_{2}}=\mathrm{CH}\right) .6 .75$ (dd. $\left.1 \mathrm{H}, \mathrm{CH}_{2}=\mathrm{CH}-\mathrm{Ar}\right), 7.45-7.60(\mathrm{~m}, 4 \mathrm{H}$, Ar).

BDAC. A solution of compound 1-3 ( $1.0 \mathrm{~g} .1 .+\mathrm{mmol})$ and iodomethane $(1.0 \mathrm{~g} .7 \mathrm{mmol})$ in acetone was stirred at $20^{\circ} \mathrm{C}$ for $+\mathrm{h}$. Unreacted methyl iodide was removed under a reduced pressure. The resulting solution was crystallized from hexane to obtain the tetralky lammonium iodide which was then dissolved in methanol and passed three times through a column packed with Amberlite IRA-400 (Cl). an ion-exchange resin. Methanol was removed under a reduced pressure to obtain $0.90 \mathrm{~g}$ of BDAC as a solid $(86 \%)$ IR $\left(\mathrm{KBr}, \mathrm{cm}^{-1}\right)$ 1640, $1100 .{ }^{1} \mathrm{H}-\mathrm{NMR}\left(\mathrm{CDCl}_{3}\right) \delta 1.23-1.90(\mathrm{~m}$. $\left.28 \mathrm{H},\left(\underline{\mathrm{CH}_{2}}\right)^{-}\right), 2.30-2.50$ (t. $\left.4 \mathrm{H}, \underline{\mathrm{CH}_{2}} \mathrm{CO}_{2}\right), 3.28$ (s, $6 \mathrm{H}$. $\left.\left(\mathrm{CH}_{3}\right) \mathrm{N}\right), 3.43$ (t. $\left.+\mathrm{H} . \underline{\mathrm{CH}}_{2} \mathrm{O}\right) .3 .74\left(\mathrm{~m} .8 \mathrm{H} . \mathrm{NCH}_{2} \underline{\mathrm{CH}}_{2} \mathrm{~N}\right)$, 4.35 (s. $+\mathrm{H} . \mathrm{ArCH}=\mathrm{O}$ ). 5.40 (d. $2 \mathrm{H} . \mathrm{CH}_{2}=\mathrm{CH}$ ), 5.90 (d. $2 \mathrm{H}$, $\left.\underline{\mathrm{CH}_{2}}=\mathrm{CH}\right) .6 .75$ (dd. $\left.1 \mathrm{H}, \mathrm{CH}_{2}=\underline{\mathrm{CH}}-\mathrm{Ar}\right), 7.45-7.60(\mathrm{~m}, 4 \mathrm{H}$, Ar). Elemental analysis (\%); Calcd for $\mathrm{C}_{1.1} \mathrm{H}_{-1} \mathrm{O}_{1} \mathrm{NCl}: \mathrm{C}$ 82.3: N 6.6: H 11.1. Found: C 81.8: N 6.5: H 11.7.

4,4'-Bis(6-hyd roxyhexyloxy)biphenyl (2-1). Potassium carbonate $(3.0 \mathrm{~g}, 20 \mathrm{~mm}$ ol) was added to a solution of 4.4 Biphenol (2.0 g. $1.07 \mathrm{mmol})$ and 6-chloro-hexan- $1-0 \mathrm{l}(4.39$ g. $3.2 \mathrm{mmol}$ ) in DMF and refluxed for 19 h at $120^{\circ} \mathrm{C}$ under a nitrogen atmosphere. The mixture was filtered to remove potassium carbonate and the solvent was removed under a reduced pressure. The residue was dissolved in benzene and cooled to $-30^{\circ} \mathrm{C}$. and cristallized to obtain $3.3+\mathrm{g}$ of compound 2-1 as a white solid (81\%). IR ( $\left.\mathrm{KBr} . \mathrm{cm}^{-1}\right) 3300$. 1100. ${ }^{1} \mathrm{H}-\mathrm{NMR}\left(\mathrm{CDCl}_{3}\right): \delta 1.38\left(\mathrm{~mL}, 8 \mathrm{H}, \mathrm{CH}_{2} \mathrm{CH}_{2} \mathrm{CH}_{2} \mathrm{CH}_{2} \mathrm{O}\right)$, 1.57 (m. $\left.4 \mathrm{H}, \underline{\mathrm{CH}_{2}} \mathrm{CH}_{2} \mathrm{O}\right) .1 .71$ (m. $\left.+\mathrm{H} . \mathrm{ArOCH}_{2} \mathrm{CH}_{2}\right) .3 .50$

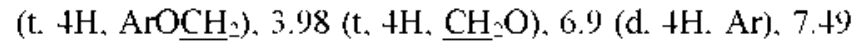
(d. $4 \mathrm{H}, \mathrm{Ar}$ ).

4,4'-Bis(6-hem isuccinyloxyhexyloxy)biphenyl (2-2). Compound 2-1 (1.5 g. $0.38 \mathrm{mmol})$ and succinic anhydride (1.56 g. $1.55 \mathrm{mmol}$ ) were dissolved in toluene and refluxed for $3 \mathrm{~h}$ at $110^{\circ} \mathrm{C}$ under a nitrogen atmosphere. The mixture was precipitated at room temperature and filtered. The precipitate was dissolved in THF, followed by the addition of ethyl acetate. The resulting solution was cooled to $-10^{\circ} \mathrm{C}$ to remove unreacted succinic antydride which is soluble in ethyl acetate. The precipitate was isolated by vacuum filteration, and dried to yield $2.03 \mathrm{~g}$ of compound 2-2 as a white solid $(90 \%)$. IR (KBr. cm$\left.{ }^{-1}\right) 3400-2400,1730,1100$. ${ }^{\prime} \mathrm{H}-\mathrm{NMR}\left(\mathrm{CDCl}_{3}\right): \delta 1.38\left(\mathrm{~m} .8 \mathrm{H} . \underline{\mathrm{CH}}_{2} \underline{\mathrm{CH}}_{2} \mathrm{CH}_{2} \mathrm{CH}_{2} \mathrm{O}\right) .1 .57$ 
(m. $\left.4 \mathrm{H}_{1} \mathrm{CH}_{2} \mathrm{CH}_{2} \mathrm{O}\right), 1.71$ (m. $\left.+\mathrm{H}, \mathrm{ArOCH}_{2} \mathrm{CH}_{2}\right) .2 .56$ (t. $8 \mathrm{H}$. $\mathrm{CH}_{2} \mathrm{CH}_{2} \mathrm{CO}_{3}$ ). 3.50 (t. $\left.4 \mathrm{H}, \mathrm{ArOCH}_{2}\right) .3 .98$ (t. $+\mathrm{H} . \mathrm{CH}_{2} \mathrm{O}$ ). 6.9 (d. + H. Ar). 7.49 (d. $+\mathrm{H}, \mathrm{Ar}$ ).

4,4'-Bis]6-\{2-(N,N-diethylamino)ethyl\}oxysuccinyloxyhexyloxy]biphenyl (2-3). Potassium carbonate $(3.0 \mathrm{~g} .20$ munol) was added to a solution of compound 2-2 $(1.0 \mathrm{~g} .0 .17$ mmol) and 2-dietlyylaminoetlỵl clloride hydroclloride (0.62 g. $0.36 \mathrm{mmol}$ ) in DMF and refluxed at $80{ }^{\circ} \mathrm{C}$ for $5 \mathrm{~h}$ under a nitrogen atmosphere. The mixture was filtered to remove potassium carbonate and exaporated to remove DMF under a reduced pressure. The residue was dissolved in benzene and washed twice with water. The benzene layer was dried over magnesium sulfate and exaporated to obtain $0.97 \mathrm{~g}$ of compound $2-3$ as a colorless liquid $(80 \%)$. IR $\left(\mathrm{KBr} \mathrm{cm}^{-1}\right) 1730,1240.1160 .{ }^{1} \mathrm{H}-\mathrm{NMR}\left(\mathrm{DMSO}-\mathrm{d}_{6}\right): \delta 1.16$ (t. $12 \mathrm{H}, \mathrm{CH}_{3} \mathrm{CH}_{2} \mathrm{~N}$ ), 1.38 (1m. 8H. $\mathrm{CH}_{2} \mathrm{CH}_{2} \mathrm{CH}_{2} \mathrm{CH}_{2} \mathrm{O}$ ), 1.57 (m. $4 \mathrm{H}, \mathrm{CH}_{2} \mathrm{CH}_{2} \mathrm{O}$ ). 1.71 (m. $+\mathrm{H} . \mathrm{ArOCH} \mathrm{CH}_{2}$ ). 2.48 (q. 12H. $\mathrm{CH}_{3} \mathrm{CH}_{2} \mathrm{~N}$ ), 2.56 (t. $4 \mathrm{H} . \quad \mathrm{CH}_{2} \mathrm{CH}_{2} \mathrm{~N}$ ). 2.56 (t. $8 \mathrm{H}$. $\mathrm{CH}_{2} \mathrm{CH}_{2} \mathrm{CO}_{2}$ ). 3.50 (t. $+\mathrm{H}$. $\mathrm{ArOCH}$ ). 3.98 (t. $+\mathrm{H}, \mathrm{CH}_{2} \mathrm{O}$ ). $4.38\left(\right.$ t. $\left.4 \mathrm{H}, \mathrm{CH}_{2} \mathrm{CH}_{2} \mathrm{~N}\right) .6 .9$ (d. $\left.4 \mathrm{H}, \mathrm{Ar}\right) .7 .49$ (d. $\left.+\mathrm{H} . \mathrm{Ar}\right)$.

BPAS. Compound 2-3 (0.97 g. $0.135 \mathrm{mmol})$ and bromoethane (2 $\mathrm{mL})$ were dissolved in THF and refluxed at $70^{\circ} \mathrm{C}$ for $2+\mathrm{h}$. The solvent and unreacted bromoethane were removed under a reduced pressure to obtain $1.07 \mathrm{~g}$ of BPAS as a white solid $(85 \%)$. IR $\left(\mathrm{KBr} . \mathrm{cm}^{-1}\right) 1730,1240,1160$. ${ }^{1} \mathrm{H}-\mathrm{NMR}$ (DMSO- $\left.d_{6}\right): \delta 1.16\left(\mathrm{t} .18 \mathrm{H} . \mathrm{CH}_{3} \mathrm{CH}_{2} \mathrm{~N}\right), 1.38(\mathrm{~m}$. $\left.8 \mathrm{H}, \mathrm{CH}_{2} \mathrm{CH}_{2} \mathrm{CH}_{2} \mathrm{CH}_{2} \mathrm{O}\right) .1 .57\left(\mathrm{~m},+\mathrm{H} . \mathrm{CH}_{2} \mathrm{CH}_{2} \mathrm{O}\right), 1.71(\mathrm{~m}$. 4H. $\mathrm{ArOCH}_{2} \mathrm{CH}_{2}$ ). 2.48 (q. $\left.12 \mathrm{H} . \mathrm{CH}_{3} \mathrm{CH}_{2} \mathrm{~N}\right) .2 .56(\mathrm{t}, 4 \mathrm{H}$. $\mathrm{CH}_{2} \mathrm{CH}_{2} \mathrm{~N}$ ). 2.56 (t. $\left.8 \mathrm{H} . \mathrm{CH}_{2} \mathrm{CH}_{2} \mathrm{CO}_{2}\right) .3 .50$ (t. $+\mathrm{H} . \mathrm{ArOCH}$ ). 3.98 (t. $\left.+\mathrm{H} . \mathrm{CH}_{2} \mathrm{O}\right), 4.38$ (t. $\left.+\mathrm{H} . \mathrm{CH}_{2} \mathrm{CH}_{2} \mathrm{~N}\right) .6 .9$ (d. $\left.+\mathrm{H} . \mathrm{Ar}\right)$. 7.49 (d. $4 \mathrm{H}, \mathrm{Ar}$ ). Elemental analysis (\%); Calcd for $\mathrm{C}_{83} \mathrm{H}_{7} \mathrm{O}_{10} \mathrm{~N}_{2} \mathrm{Br}_{2} \mathrm{H}_{2} \mathrm{O}: \mathrm{C} 56.5 ; \mathrm{H} 7.9: \mathrm{N} 2.7$. Found: $\mathrm{C} 56.3: \mathrm{H}$ 8.2: N 2.5.

Preparation of vesicles. BDAC and BPAS in a $3: 1$ molar ratio were dissolved in clloroform/methanol (3/1), followed by the addition of a 2.2 -azobisisobuty mitrile (AIBN) solution $(10 \mathrm{~mol} \%)$ in clloroform. The resulting solution was slowly evaporated to obtain a thin film of the surfactant mixture on the inner wall of the vial, and dried further under a ligh vacuum for at least $\mathrm{l} \mathrm{h}$. The dried film was then hrydrated with the repeated freeze-thaw cycles $\left(-70^{\circ} \mathrm{C} \sim 50^{\circ} \mathrm{C}\right)$.

Dynamic Light Scattering (DLS). The vesicle size was estimated with DLS measurements. All measurements (10 $\mathrm{mg}$ surfactant $/ 2 \mathrm{~mL}$ water) were performed at $25^{\circ} \mathrm{C}$ and 90 "C using a BI 8000-AT (Brookhaven lnstruments Corp.). The mean diameter of vesicles was calculated by multiple mathematical procedures.

Polymerization of vesicles. Vesicles composed of BDAC/ BPAS (3/1) containing AlBN were prepared as described above $(\mathrm{BDAC} / \mathrm{AlBN}=5 / 2)$. DVB was injected into the resicle dispersion using a microliter syringe, and the resulting mixture was stirred for 2 days at room temperature to ensure a complete incorporation of the cross-linking agent into the lipid bilayers (BDAC/DVB $=1 / 1$ ). The dispersion was stirred at room temperature for $48 \mathrm{~h}$. and then stirred at $50^{\circ} \mathrm{C}$ for at least $24 \mathrm{~h}$. Nitrogen was bubbled through the solution to eliminate oxygen in the samples.
Skeletonization and hydrolysis of polymerized vesicles. The polymerized vesicle suspensions were dried. and suspended in $10 \mathrm{~mL}$ of methanol in order to remove BPAS. The resulting mixtures were centrifugated at $13000 \mathrm{rpm}$. and decanted to remove the supernatant. The same procedure was repeated twice. A concentrated $\mathrm{HCl}$ aqueous solution was added to the skeletonized vesicle suspension until the final $\mathrm{HCl}$ concentration attained was $12 \mathrm{wt} \%$. The resulting suspension was then stirred at $50^{\circ} \mathrm{C}$ for $48 \mathrm{~h}$. followed by centrifugation. The supernatant was decanted off. and the precipitate was resuspended with water. and then centrifugated. This overall procedure was repeated thrice in order to remove any by products formed during the hydroly sis.

Transmission Election Microscopy (TEM). The samples were stained with $2 \mathrm{wt} \%$ phosphotungstic acid $(\mathrm{pH} 6.8$ with l $\mathrm{N} \mathrm{KOH}$ ) for $1 \mathrm{~h}$ on a parafilm (vesicle sample/phosphotungstic acid $=1: 1 . \mathrm{v} / \mathrm{v})$. covered formvar/carbon grid for $1 \mathrm{~min}$. The residual sample was removed from the grid with filter paper. The samples were washed with water and dried in vaccum. TEM images were obtained using a transmission electron microscope (EMIOCR. Carlzeiss Co.) at $60.0 \mathrm{kV}$.

\section{Results and Discussion}

Synthesis. BDAC was synthesized in five consecutive

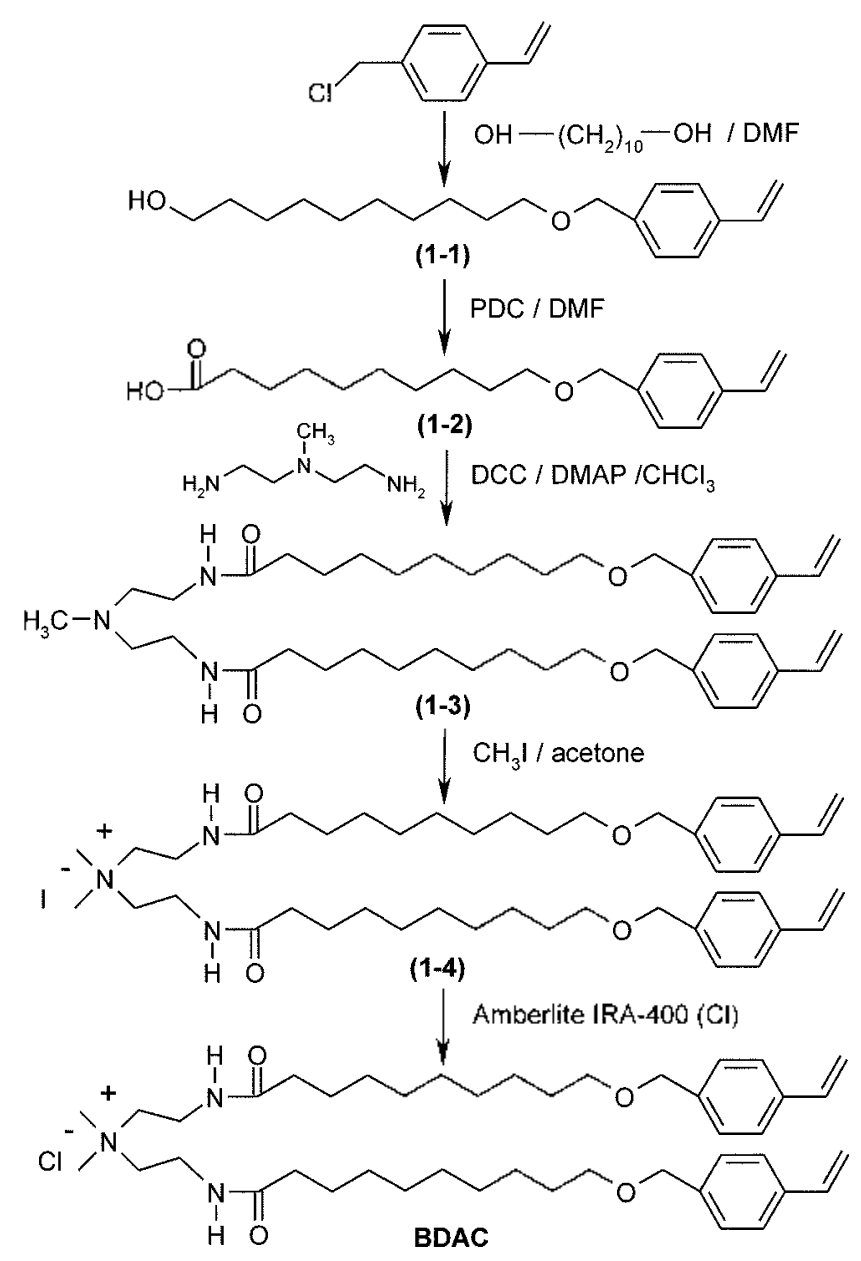

Scheme 1. Svinthetic toute to BDAC. 

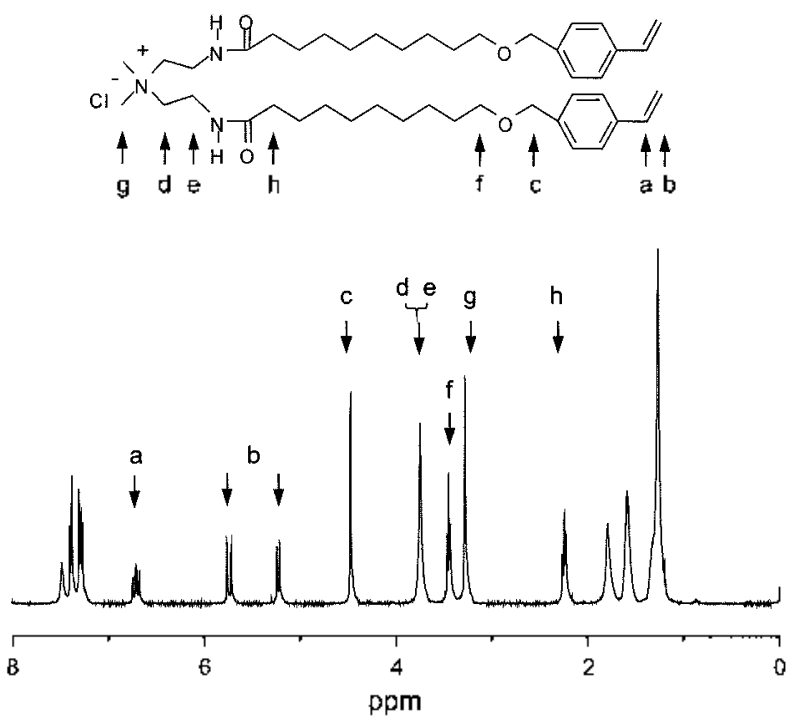

Figure 2. 'H-NMR (CDCl$l_{3}$ ) spectrum of $\mathrm{BDAC}$.

steps. as shown in scheme 1. 4-Vinylbenzyl chloride was reacted with 1,10-decanediol to yield compound 1-1 which was oxidized to give compound 1-2. The carboxylic acid was then amidized with $\mathrm{N}$-methy 1-2.2 `-diaminodiethy lamine in the presence of DCC to yield compound 1-3. The tertiary amine was quatemarized with excess iodomethane. The resulting tetraalkylammonium iodide (1-4) was ion-exchanged using an ion exchange resin. Amberlite IRA-400(Cl). to obtain BDAC as a white solid. Even though the synthesis consisted of five steps from 4 -vinylbenzy l chloride and 1.10decanediol. most of the reactions were efficient and the overall yield was about $20 \%$.

The FT-IR spectnum of BDAC showed strong absorption peaks at 3300 and $1640 \mathrm{~cm}^{-1}$. which correspond to the $\mathrm{N}-\mathrm{H}$ and carbonyl group of the amide bonds, respectively. The proton NMR spectrum of BDAC was interpreted, as shown in Figure 2. The most characteristic resonance peaks are those of vinyl protons at 5.40-6.75 ppm. methylene protons next to carbonyl at $3.28 \mathrm{ppm}$, and dimethyl protons at 3.43 ppm. Thus. the FT-IR and NMR spectra confirmed that the isolated compound had the expected chemical structure of BDAC. No impurity peak was detected in the NMR spectrum. The elemental analysis data along with the NMR spectrum confirmed that the isolated compound was pure enough for the next experiments.

BPAS. a nompolymerizable bipolar surfactant, was synthesized by the reactions shown in Scheme 2. The synthesis was accomplished in four different steps. 4.4-Biphenol was reacted with 6-chlorohexam-1-ol in DMF to yield compound 2-1 which was coupled with succinic antydride in toluene to obtain compound 2-2. The dioic acid was coupled further with N.N-diethylaminoethyl chloride hy drochloride in DMF to yield compound 2-3 which was reacted with bromoethane in THF to yield compound 2. The overall yield was about $50 \%$. The FT-IR spectrum of BPAS showed a peak at 1730 $\mathrm{cm}^{-1}$. which corresponds to the ester carbonyl group. The proton NMR spectrum of BPAS is shown in Figure 3. The most characteristic resonance peaks are those for methylene protons next to ester carbonyl group (triplet at $2.56 \mathrm{ppm}$ ) and another methylene protons on carbons linked to the ether oxygen atom (triplet at $3.50 \mathrm{ppm}$ ). Thus. the FT-IR and NMR spectra confirmed that the isolated compound had the expected chemical structure of BPAS. The elemental analysis data suggests that the isolated each molecule was hydrated with one molecule of water, which is not uncommon for hy groscopic salts.

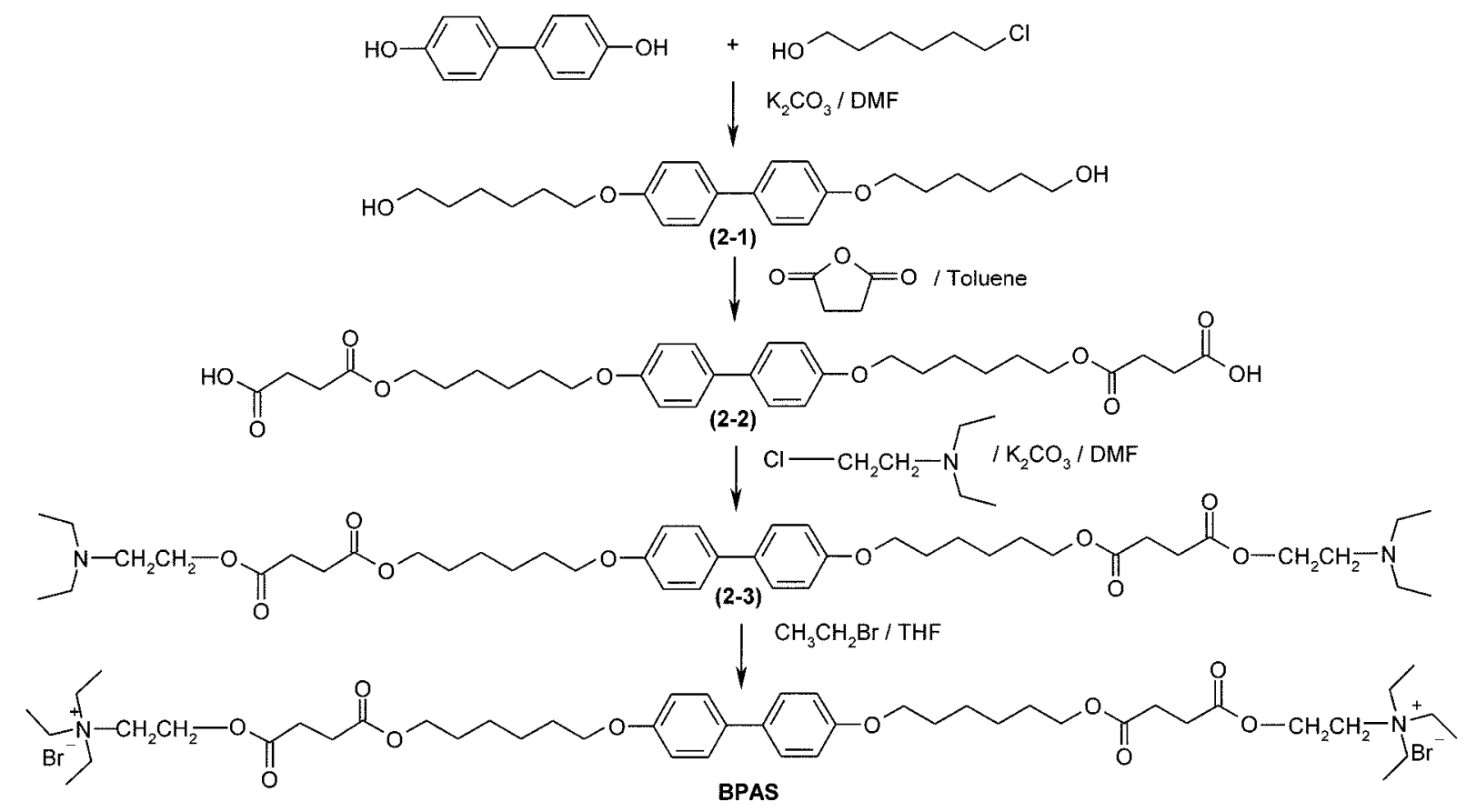

Scheme 2. S\&nthetic route to BPAS. 

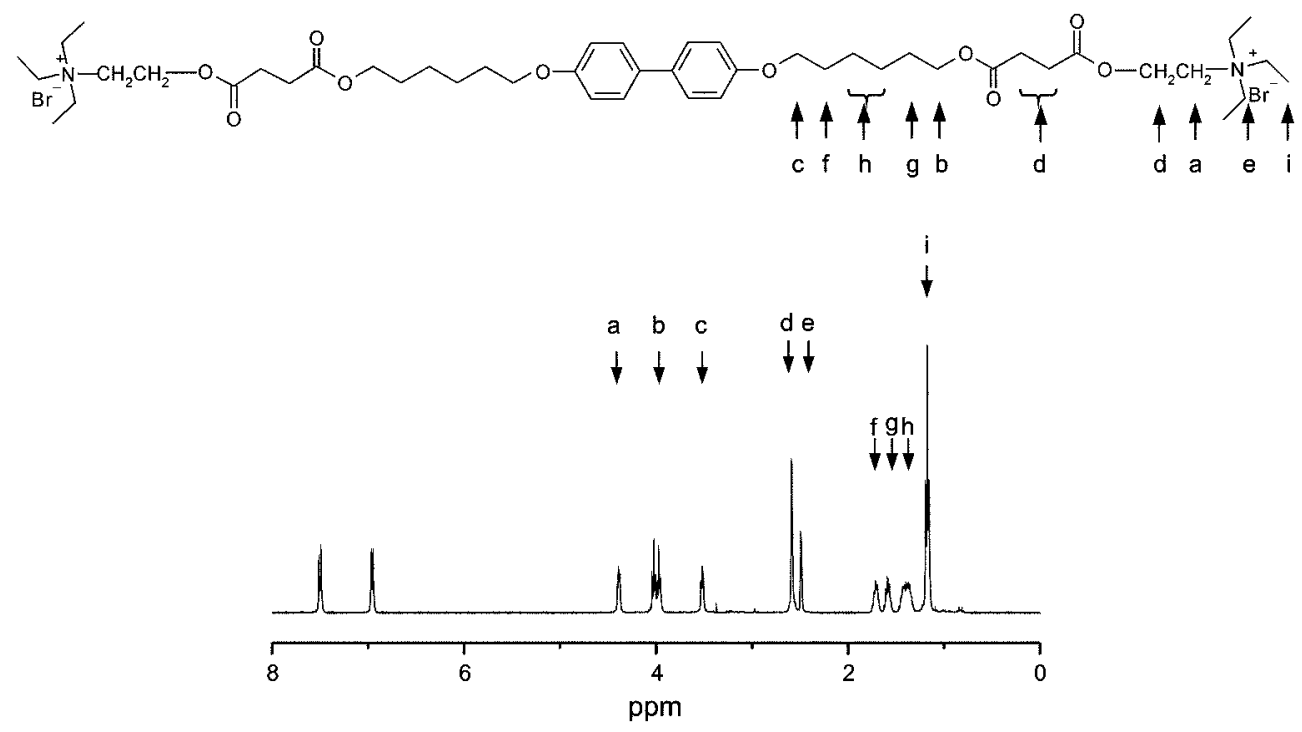

Figure 3. 'II-NMR (LMSO-di) spectrum ol BPAS.
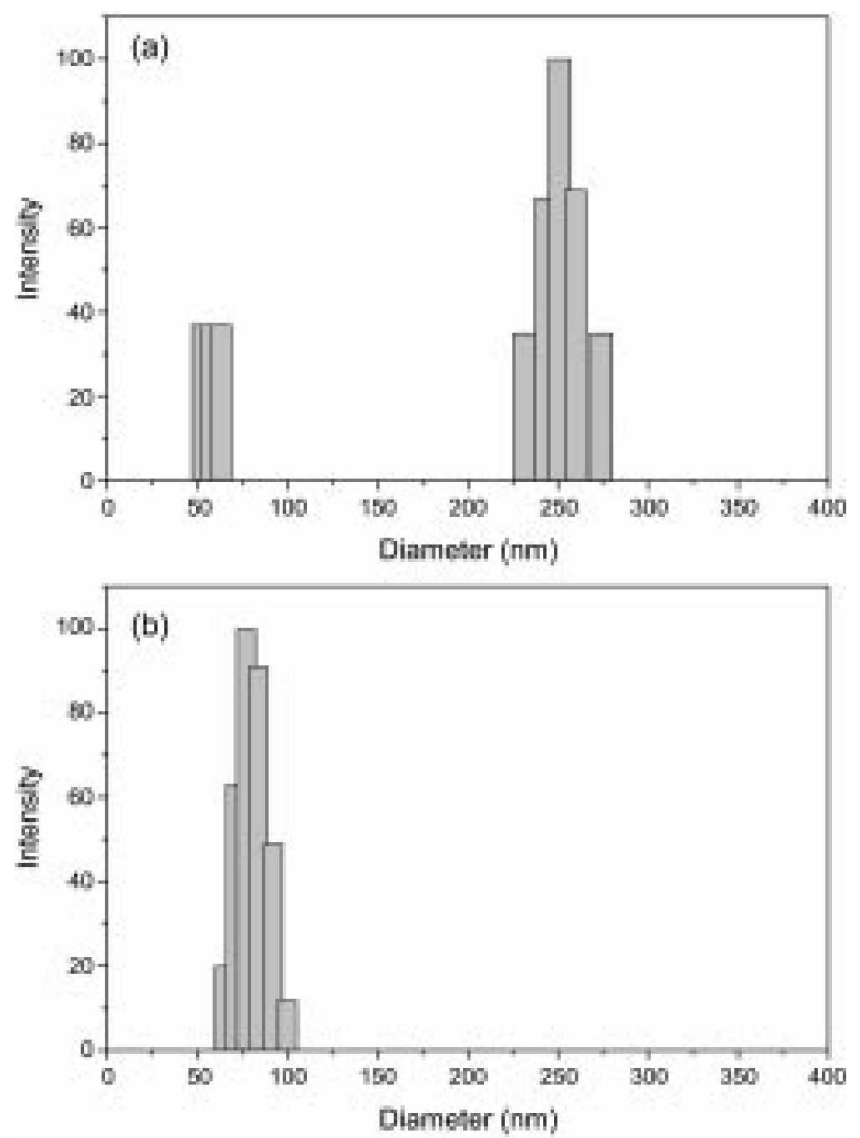

Figure 4. Size distributions of vesicles in water prepared from BPAS (a) before and (b) atter ultrasonication.

General properties. BDAC did not form vesicles by itself. A surfactant of ammonium salt whose chemical structure is very similar to that of BDAC was also reported not to form vesicles. ${ }^{8}$ Probably the bulky phenyl group at each hydrophobic chain termimus may prevent the molecule from assembling in a bilaver. On the other hand. even before ultrasonication the hydrated BPAS did form vesicles whose size distribution was bimoidal with mean diameters of about $60 \mathrm{~lm}$ and $250 \mathrm{~nm}$. respectively. as shown in Figure 4 . However. after ultrasonication. the distribution became unimoidal with mean diameter of about $80 \mathrm{~nm}$. Some bipolar surfactants were reported to also form vesicles by themselves on hydration. but some others needed a second component such as cholesterol to form vesicles. ${ }^{9-11}$

Mixtures of BDAC and BPAS in proper molar ratios formed large vesicles with mean diameter of about $500 \mathrm{~nm}$ on hydration. Vesicles prepared from BDAC and BPAS in a 3:1 molar ratio exhibited a unimoidal distribution with mean diameter of 130 mu on ultrasonication. The small vesicles prepared from BDAC and BPAS were stable for weeks since there was no precipitate fomed and its transparency was not changed during the storage of the dispersions at room temperature.

Differential scanming calorimetry (DSC) experiments were performed in order to know the chain-melting temperature $\left(\mathrm{T}_{\mathrm{m}}\right)$ of respective surfactant bilayer above where polymerization reaction usually occurs (2910 TA Instrument). Any phase transition was not observed either from BDAC or BPAS dispersions in the temperature range from $0^{\circ} \mathrm{C}$ to $90^{\circ} \mathrm{C}$. as shown in Figure 5. The absence of melting transition for the BDAC dispersions is understandable because BDAC did not form resicle membranes by itself, as mentioned above. On the other hand. vesicles prepared from DPPC and BPAS undervient a melting transition at $48.8^{\circ} \mathrm{C}$. The transition corresponds to the melting transition of DPPC bilavers since pure DPPC bilayers undenwent the transition at about $43^{\circ} \mathrm{C}$ according to our experiment ${ }^{\prime \prime}$ A slight higher $T_{m}$ of DPPC domains may be due to closer packing of DPPC molecules in the presence of BPAS. The DSC curve does not show any other melting transition indicating that BPAS domians do not undergo a melting transition in the temperature range studied. The absence of the melting transition of BPAS domains suggests that the bipolar membranes may be in a 


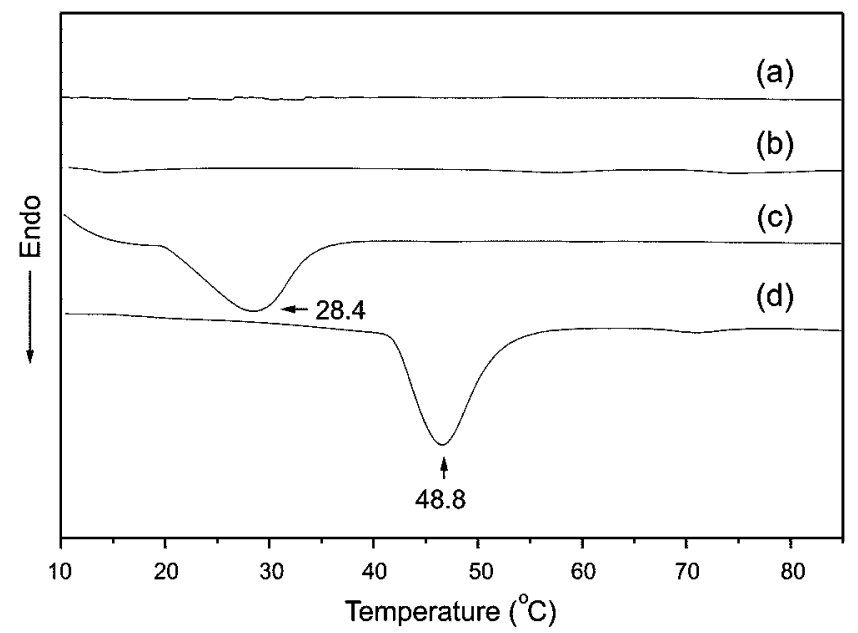

Figure 5. DSC themograms of (a) $\mathrm{BD} \wedge \mathrm{C}$, (b) BDAS, (c) BDAC/ BPAS $(3 / 1)$, and (d) BPAS/DPPC (1/1) dispersions.

gel phase in the temperature range due to the rigid biphenyl segment and relatively long chain length.

However. vesicles prepared from BDAC and BPAS in a 3 : 1 molar ratio exhibited a melting transition with $\mathrm{T}_{11} 28.4^{\circ} \mathrm{C}$. Based on the experiment with vesicles prepared from DPPC and BPAS. the BPAS membrame does not undergo melting transition in the temperature range. Thus this DSC result suggests that BDAC molecules in the mixed membranes undergo melting transition and change into a liquid-like state above $28.4^{\circ} \mathrm{C}$. indicating that polymerization of the membranes can be easily performed using a radical initiator such as AlBN.

Polymerization, skeletonization, and hydrolysis of vesicles. Large vesicle $(\sim 500 \mathrm{~nm})$ dispersions prepared from BDAC. BPAS. and DVB in a 3:1:1 molar ratio were polymerized at $50^{\circ} \mathrm{C}$ in the presence of AIBN (BDAC/ AlBN $=5 / 2$ ) under bubbling of nitrogen gas for $2+\mathrm{h}$. The proton NMR spectnum of the polymerized sample dried in a vacuum oven revealed that the vinyl protons of the polymerizable groups in BDAC and DVB had disappeared.

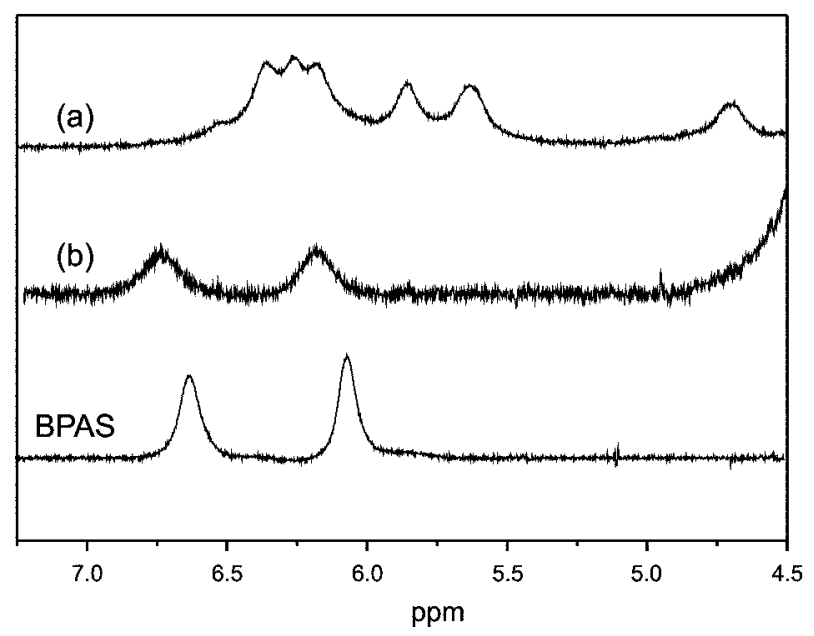

Figune 6. 'H-NMR spectra of' sonicated vesicles prejared from BDAC/BPAS cmbedded with DVB (a) belore polymerization and (b) alter polymerization and BPAS (conc. $20 \mathrm{mg} / \mathrm{mL}$ of $\mathrm{D}_{2} \mathrm{O}$ ).

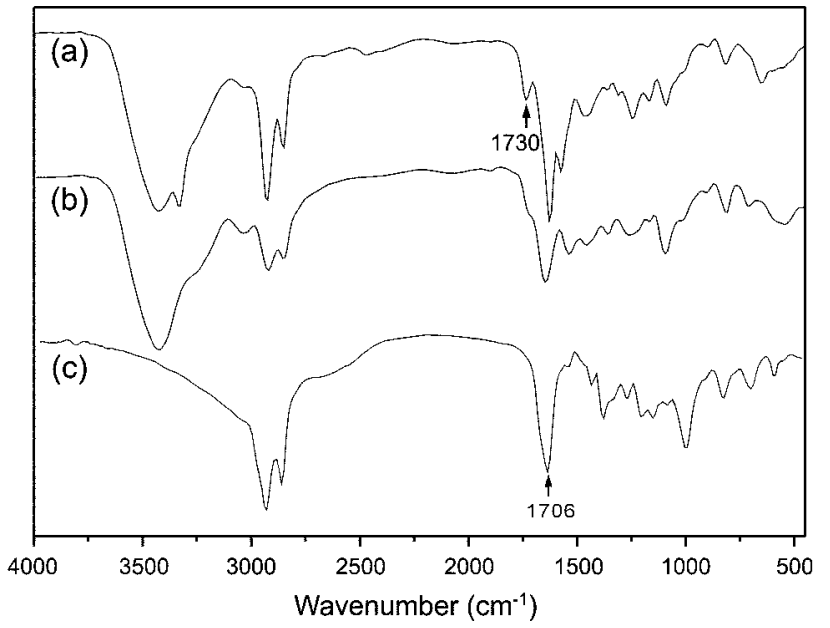

Figure 7. H I-IR specira of large vesicles alter (a) polymerization, (b) skeletonization, and (c) hydrolysis.

as shown in Figure 6. This result indicates that BDAC and DVB were almost completely reacted.

The polymerized resicle suspensions were dried and washed with methanol in order to remove BPAS from the vesicle membranes since BPAS is well soluble in methanol. The FT-IR spectrum of the resulting dried vesicles revealed that BPAS molecules were removed since characteristic FTIR peaks for ester carbonyl groups of BPAS disappeared, as shown in Figure $7 \mathrm{~b}$. This result suggests that the polymerized vesicles might be skeletonized by the loss of BPAS if any significant size of BPAS domains had been induced by the radical poly merization.

A concentrated $\mathrm{HCl}$ solution was added to the skeletonized vesicle suspension until the final concentration of $\mathrm{HCl}$ in the dispersion became $12 \mathrm{w} \%$. The resulting dispersion was stirred at $50^{\circ} \mathrm{C}$ for $48 \mathrm{~h}$ and centrifugated at $13000 \mathrm{rpm}$ for $5 \mathrm{~min}$. and then finally a white precipitate was obtained. The precipitate was purified further by repeating the centrifugation procedure. Figure $7 \mathrm{c}$ is a FT-IR spectrum of the purified precipitate. The absorption peaks of amide group at about $3+00$ and $165+\mathrm{cm}^{-1}$ disappeared and those of carboxyl group at about $3500-2400 \mathrm{~cm}^{-1}$ and $1706 \mathrm{~cm}^{-1}$ emerged quite clearly. This result indicates that the quaternary anmonium head groups of the polymerized BDAC units were completely removed via hydrolysis.

Transmission electron microscopy (TEM) experiments were performed in order to visualize the vesicles. TEM micrographs of the vesicles are shown in Figure 8. The approximate spherical vesicle shape retained even after skeletonization and hydrolysis. The skeletonized vesicles appear to have many holes with diameters up to about 25 $\mathrm{nm}$. The holes retained even after hydrolysis. This result indicates that most vesicles were sufficiently stabilized by the cross-linking process during poly merization. It seems to be that small vesicular particles are coexisting with regular vesicles after hydrolysis to some more extent. The formation of the additional small assemblies or aggregates may be due to cleavage of some polymer main chains in uncross-linked vesicles during hrdrolysis under the such strong acidic 


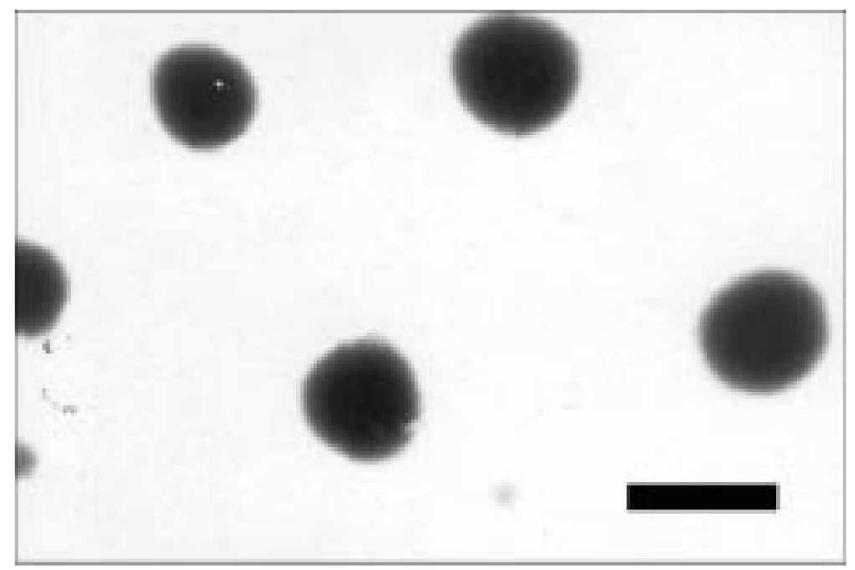

(ㅂ)

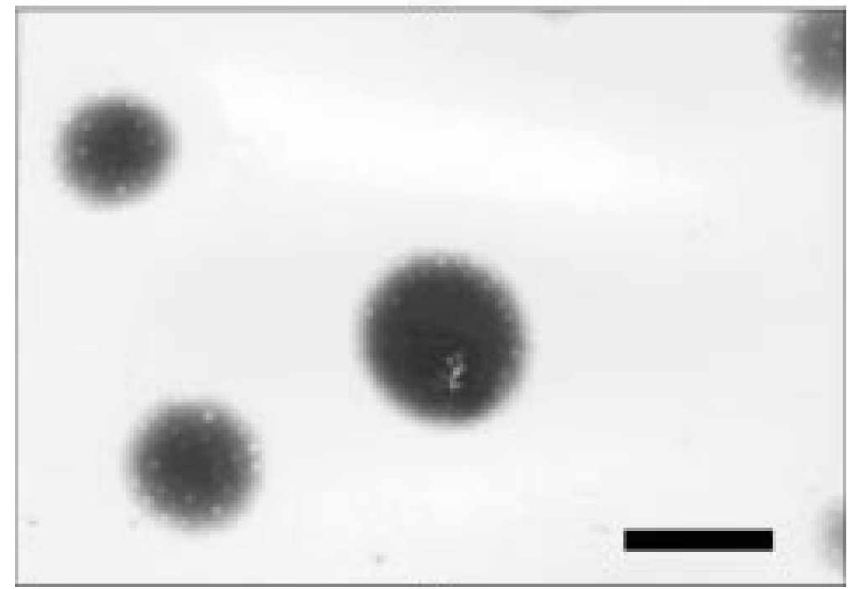

(b)

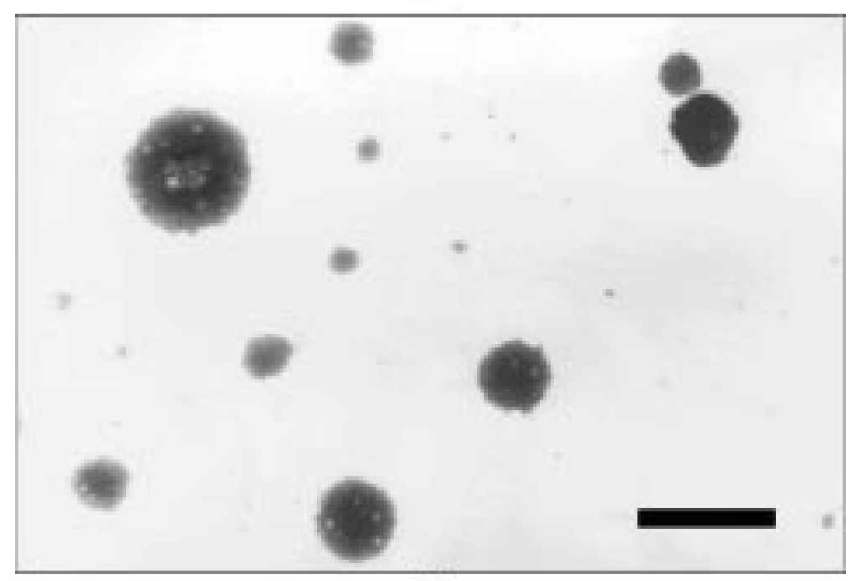

(0)

Figure 8. TLM micrographs of laroc vesicles alter (a) polymcrization. (b) skeletonization, and (c) hydrolysis. The bar indicates $500 \mathrm{~nm}$.

conditions.

The hydrolyzed vesicles were not dispersed in water any longer. but precipitated. This result indicates that the polarity of the hydrolyzed vesicle surfaces was significantly reduced and their compatibility with water was greatly reduced accordingly. The lydrolyzed vesicles were attempted to be dispersed in organic solvents such as THF and clloroform. but they did not disperse. However. a very stable milky suspension of the lydrolyzed vesicles forned in methanol. This result indicates that the hydrolyzed vesicle surfaces are much less polar than the initial ones. but still too polar to be dispersed in such conmonon organic solvents.

\section{Conclusion}

BDAC and BPAS were successfully synthesized in multisteps. BDAC did not form vesicles by itself while BPAS did form vesicles. Large vesicles composed of BDAC and BPAS with embedded DVB underwent radical polymerization. BPAS was removed from the cross-linked vesicles using methamol. The headgroup of BDAC was removed via hydrolysis in the acidic condition. According to TEM micrographs, the overall spherical shape retained after hydrolysis even though much smaller particles emerged to some more extent. Many holes with diameters up to $25 \mathrm{~nm}$ were observed from the skeletonized and hydrolyzed vesicles, and they retained even after hydrolysis. The hydrolyzed vesicles did not disperse in water, but dispersed in methanol. They were not dispersed either in organic solvents such as THF and chloroform. The hydrolyzed vesicle surfaces will be further modified so that the resulting porous vesicles can be dispersed in conmon organic solvents and the result will be reported in near future.

Acknowledgement. This work was supported by the Basic Research Program of the Korea Science \& Engineening Foundation (Grant No. R05-2000-(00343-0).

\section{References}

1. Armitage, B.: Bennett. D. Г.: I.amparski. H. G.: O'Bricn. D. Г. ids: Polvm. Sct 1996. 126. 53 .

2. OBrien. D. F: Amitage. B.: Benedicto. A.: Bemell. D. E.: Lamparski. H. G.: Lee. Y.-S.: Srisiri. W.: Sisson. T. M. fac. Chem. Res. 1998. 31.861.

3. Ringsdort, II: Sclularb. B.: Venzmer. I. Inge'w. Chem. Int. Fd. Fingl. 1988. 27, 113.

4. Olno. II.: Tahcoka. S.: Tsuchida. F. Polym. Bull 1985. If. 487.

5. Yang. W. Y.: Hahn. Y. B.: Nahm. K. S.: Lee. Y.-S. Bull. Korean Chem. Soc. 2001. 22.1201.

6. Yang. W. Y.: Lee. Y.-S. Lomgmmir 2002. 18.6071.

7. Jeme. M. II.: J ce. Y. S.: Jir. J. Y.: Ko. S. B. Bull. Kon'an Chem. Soc. 1996, 17, 875

8. Jung, M.: den Ouden, I.: Montoya-Goni, A.: Hubcrt, D. II. W.: Frederik. I'. M.: van Herk. A. M.: German. A. L. Lamgmmir 2000. 16. 4185 .

9. Okahata. Y.: Kunitake. T. J. J. .tm. Chem. Soc. 1979.101. 5231.

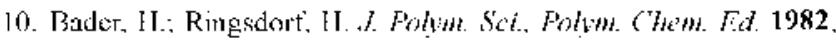
20.162 .3

11. Bader, I1.; Ringsdonf, It. Faradon: Fisctuss (Th'm. Soc. 1986. 81, 329. 